\title{
$\begin{array}{r}\text { WAGENINGEN } \\ \hline\end{array}$
}

\section{Influence of different redox conditions and dissolved organic matter on pesticide biodegradation in simulated groundwater systems}

Luo, Y., Atashgahi, S., Rijnaarts, H. H. M., Comans, R. N. J., \& Sutton, N. B.

This is a "Post-Print" accepted manuscript, which has been published in "Science of the Total Environment"

This version is distributed under a non-commercial no derivatives Creative Commons (c) (1) (9) (CC-BY-NC-ND) user license, which permits use, distribution, and reproduction in any medium, provided the original work is properly cited and not used for commercial purposes. Further, the restriction applies that if you remix, transform, or build upon the material, you may not distribute the modified material.

Please cite this publication as follows:

Luo, Y., Atashgahi, S., Rijnaarts, H. H. M., Comans, R. N. J., \& Sutton, N. B. (2019). Influence of different redox conditions and dissolved organic matter on pesticide biodegradation in simulated groundwater systems. Science of the Total Environment, 677, 692-699. https://doi.org/10.1016/j.scitotenv.2019.04.128 
Influence of Different Redox Conditions and Dissolved Organic Matter on Pesticide Biodegradation in Simulated Groundwater Systems

Authors: Yujia Luo ${ }^{a}$, Siavash Atashgahi ${ }^{b}$, Huub H.M. Rijnaarts ${ }^{a}$, Rob N.J. Comans ${ }^{c}$, Nora B. Sutton ${ }^{a} \dagger$ a Sub-department of Environmental Technology, Wageningen University \& Research, P.O. Box 47, 6700 AA Wageningen, The Netherlands

b Laboratory of Microbiology, Wageningen University \& Research, P.O. Box 47, 6700 AA Wageningen, The Netherlands

c Department of Soil Quality, Wageningen University, P.O. Box 47, 6700 AA Wageningen, The Netherlands

† Corresponding author. Email: nora.sutton@wur.nl; Tel.: +31(0)317483339; Postal address: P.O. Box 47, 6700 AA Wageningen, The Netherlands 


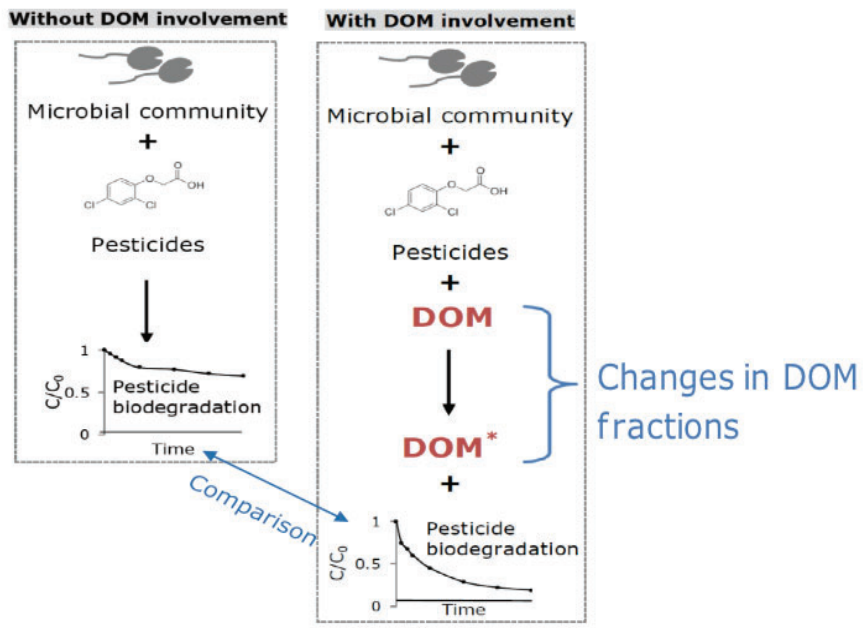

\section{Abstract}

Insights into the influence of redox conditions, that is the availability of electron acceptors, and dissolved organic matter (DOM) on pesticide biodegradation in groundwater are key to understanding the environmental fate of pesticides in natural groundwater systems. Here, the influence of redox conditions and supplemental DOM addition on biodegradation of pesticides, 2,4-dichlorophenoxyacetic acid (2,4-D), 2,6-dichlorobenzamide (BAM), mecoprop-p (MCPP) and bentazone, was tested in microcosm and subsequent column experiments. Pesticide degradation, functional genes and changes in specific fractions and quantity of DOM were systematically quantified. In aerobic microcosm experiments, the highest 2,4-D degradation rate was obtained with the presence of more assimilable DOM. In column experiments, minimal pesticide degradation $(\leq 33.77 \%)$ in any anaerobic redox conditions was observed in the absence of DOM. However, in the presence of DOM, 2,4-D biodegradation was considerably enhanced under nitrate-reducing conditions (from $23.5 \pm 10.2 \%$ to $82.3 \pm 11.6 \%$ ) and in a column without external electron acceptor amendment (from $-6.3 \pm 12.6 \%$ to $31.1 \pm 36.3 \%$ ). Observed preferential depletion of the fulvic acid fraction of DOM provides indications for specific functional DOM properties. The qPCR results show an increase in microbial biomass and functional genes (tfdA) in liquid phase after DOM addition. The results of this work provide insights into the interplays among DOM, redox geochemistry, and pesticide biodegradation, and show the potential of a novel approach - DOM addition to groundwater systems - for in situ biostimulation technology to remove pesticides from groundwater systems.

Key words: pesticide biodegradation, DOM, redox conditions, groundwater system, biostimulation 


\section{Introduction}

Groundwater is an essential freshwater resource for drinking water production in many regions of the world. However, groundwater quality is increasingly threatened by organic micropollutants, especially pesticides. The extensive use of pesticides around the world, about two million tonnes per year (De et al., 2014) combined with the persistence and mobility of pesticides results in the diffuse accumulation of pesticides in the water cycle. Pesticides can reach groundwater through leakage from soil (Stuart et al., 2011). Pesticide residues in groundwater have been detected at $\mathrm{ng} / \mathrm{L}$ to $\mu \mathrm{g} / \mathrm{L}$ concentrations range in Asia (Lee et al., 2019; Thuy et al., 2012), the United States of America (Barbash et al., 2001; Squillace et al., 2002) and Europe (Jurado et al., 2019; Loos et al., 2010; Meffe and de Bustamante, 2014; Vryzas et al., 2012). The European Union has set intervention thresholds for drinking water of $0.1 \mu \mathrm{g} / \mathrm{L}$ for individual pesticides, and $0.5 \mu \mathrm{g} / \mathrm{L}$ for total pesticides (EU, 2006). In order to safeguard drinking water quality, it is essential to understand the environmental fate and (bio)transformation of pesticides in groundwater.

Biodegradation is viewed as the most important means for natural attenuation of pesticides once they have entered groundwater (Greskowiak et al., 2017). Pesticide biodegradation is governed to a large extent by groundwater geochemistry, especially the availability of electron acceptors (redox condition) and dissolved organic matter (DOM) concentration and quality; these parameters in turn dictate microbial community diversity and degradation capacity (Boopathy, 2000). Thus, to understand and predict the environmental fate of pesticides in complex groundwater systems, it is crucial to have insight into the interplay among groundwater geochemical parameters, microbial community composition and pesticide transformation.

Redox conditions, that is electron acceptor availability, dictates pesticide biodegradation, with various compounds proving persistent in groundwater due to redox conditions (Barbieri et al., 2011; Greskowiak et al., 2017). Though a large body of information regarding the degradability of pesticides is available from regulatory testing for market authorization, regulations stipulate testing under aerobic conditions, thus providing little insight into pesticide degradation in subsurface groundwater systems that are usually oxygen limited or anoxic (Fenner et al., 2013). Furthermore, many scientific investigations examine the biodegradation of pesticides upon application in field systems under aerobic conditions (Delgado-Moreno et al., 2017; Hoppe-Jones et al., 2012; Pinoherrera et al., 2017; Robles-González et al., 2008; Znad et al., 2010). These results cannot be translated to the array of anaerobic redox conditions encountered in subsurface systems. This knowledge gap strongly limits our ability to predict the biodegradation of pesticides in anaerobic groundwater systems and evaluate the risks for drinking water production. 
In oligotrophic groundwater systems, biological activity is often limited by the availability of carbon and nutrient sources (Egli, 2010). DOM, ubiquitously present in terrestrial and aquatic environments, therefore is believed to be an important factor determining pesticide biodegradation in such oligotrophic systems. Humic substances have been regarded as macromolecular, and their molecular weight can be up to 100,000 daltons. However, humic Acids (HA) and fulvic acids (FA) are currently regarded as a complex "supra-molecular" arrangement of diverse and relatively low molecular mass components (aqueous humic extracts from soil, lignite and water range from a few hundred to 2,000 daltons), which include aromatic and aliphatic structures with associated functional groups (Leenheer and Croué, 2003; Sutton and Sposito, 2005). This new view overturns the previously acknowledged refractory nature of these humic substances (Sutton and Sposito, 2005), and thus suggests a possible role of DOM containing $\mathrm{HA}$ and FA in affecting pesticide biodegradation, either positively (for instance, by enhancing microbial biomass) or negatively (for instance, by means of catabolic repression) (Aislabie and Lloyd-Jones, 1995; Aleksieva et al., 2002; Dec et al., 1990; Helbling, 2015; Hoppe-Jones et al., 2012; Horemans et al., 2017; Horemans et al., 2013; Kim and Hao, 1999; Odukkathil and Vasudevan, 2013; Willems et al., 1996). Understanding the mechanisms by which DOM supports or inhibits pesticide biodegradation is crucial to predicting the transformation of pesticides in groundwater systems and to developing efficient in situ bioremediation approaches.

To develop a better understanding of the environmental behaviour of pesticides in actual groundwater conditions, this work studies pesticide biodegradation in simulated groundwater systems under different redox conditions. Furthermore, the influence of DOM addition was tested in order to understand the role of auxiliary carbon in pesticide degradation and to explore this potential biostimulation approach. Microcosm experiments were first conducted to test the influence of two different DOM types (different sources) on pesticide biodegradation and to select an appropriate DOM source for biostimulation in subsequent column experiments. Carefully controlled column experiments were performed to simulate groundwater systems and determine if in situ biostimulation with DOM is a potentially feasible technology for pesticide removal. The results of this work provide insights into the interplays among DOM, redox geochemistry, and pesticide biodegradation.

\section{Materials and methods}

\subsection{Chemicals and regents}

Pesticides 2,4-dichlorophenoxyacetic acid (2,4-D), 2,6-dichlorobenzamide (BAM), mecoprop-p (MCPP) and bentazone were purchased from Sigma-Aldrich (USA). These compounds have a high environmental mobility (high solubility) and consequently are frequently detected in groundwater: they are on the 
Netherlands National Institute for Public Health and the Environment (RIVM) list and were encountered 36 times in the study of 215 groundwater wells in the Netherlands (Swartjes et al., 2016). Details of the pesticide stock solutions and their physio-chemical properties are shown in Table S1 of the Supporting Information.

\subsection{DOM extraction}

Two types of DOM were used in this work. DOMGw, provided by a drinking water company (Vitens, The Netherlands), was extracted by an anion exchange resin from natural groundwater. DOMcompost was extracted from Green Compost collected from a Dutch company (Van Iersel Compost, The Netherlands), with a composition of $50 \%$ screened wood, $25 \%$ grass litter, and $25 \%$ leaf litter. Ultra-pure water (UPW) was added to compost with a ratio $4: 1$ (w/w, water to soil). The mixed suspension was homogenized for 2.5 hours by horizontal shaking at $120 \mathrm{rpm}$. The suspension was then centrifuged at $3500 \mathrm{rpm}$ for 15 min, and the supernatant centrifuged again at $9000 \mathrm{rpm}$ for 25 minutes. Finally, the supernatant solution was filtered through a $0.45 \mu \mathrm{m}$ membrane filter (Whatman-ME 25/21 ST) using a vacuum filtration system. Prior to use, DOM solution was stored at $4{ }^{\circ} \mathrm{C}$.

\subsection{Experimental set-up}

\subsubsection{Microcosm experiments}

As a proof-of-principle that DOM has potential to enhance pesticide biodegradation, microcosm experiments were performed to study the effects of DOM on 2,4-D biodegradation under aerobic condition. Prior to experiments, aerobic enrichment cultures were prepared using sludge as inoculum (Supporting Information, Cultural Enrichment Processes) in media (Table S2). This inoculum was used to test the effects of DOMcompost and DOMGw on 2,4-D biodegradation by preparing microcosms with and without DOM addition. The microcosm bottle was closed and flushed with air when the percentage of oxygen was lower than $10 \%$. Working volume of each microcosm bottle was $100 \mathrm{ml}$, containing $10 \mathrm{ml}$ liquid inoculum and $73 \mathrm{ml}$ media spiked with 2,4-D (1 mg/L) and DOM (10 mg/L). Abiotic controls were prepared with addition of $1 \mathrm{mM} \mathrm{HgCl}_{2}$ and $2 \mathrm{mM} \mathrm{NaN}_{3}$ as a reference for any abiotic degradation of 2,4-D. Nitrification was inhibited in all bottles by adding allylthiourea at $5 \mathrm{mg} / \mathrm{L}$ to exclude autotrophic cometabolic conversion of pesticides. The experiments lasted for 2 weeks, during which 2,4-D with the same concentration was re-spiked once at day 2, twice per day from day 4 to day 7 , and three times per day from day 8 to day 14 due to the observed increased degradation rate of 2,4-D. Liquid and gas samples were taken at day $0,1,4,7,10$, and 14 . Liquid samples were used for 2,4-D degradation analysis, and gas samples were used to check $\mathrm{O}_{2}$ consumption and $\mathrm{CO}_{2}$ production during 2,4-D 
biodegradation. The bottles were incubated in the dark at a temperature of $20^{\circ} \mathrm{C}$, shaking at $120 \mathrm{rpm}$. Experiments were executed in triplicate.

\subsubsection{Simulated ground water systems}

Column experiments were conducted in four continuous-fed, up-flow columns with aquifer material under different redox conditions in order to simulate groundwater systems (Figure 1). Redox conditions were nitrate-reducing, sulfate-reducing, and methanogenic. Furthermore, one column was operated without the addition of supplementary electron acceptors.

Effluent

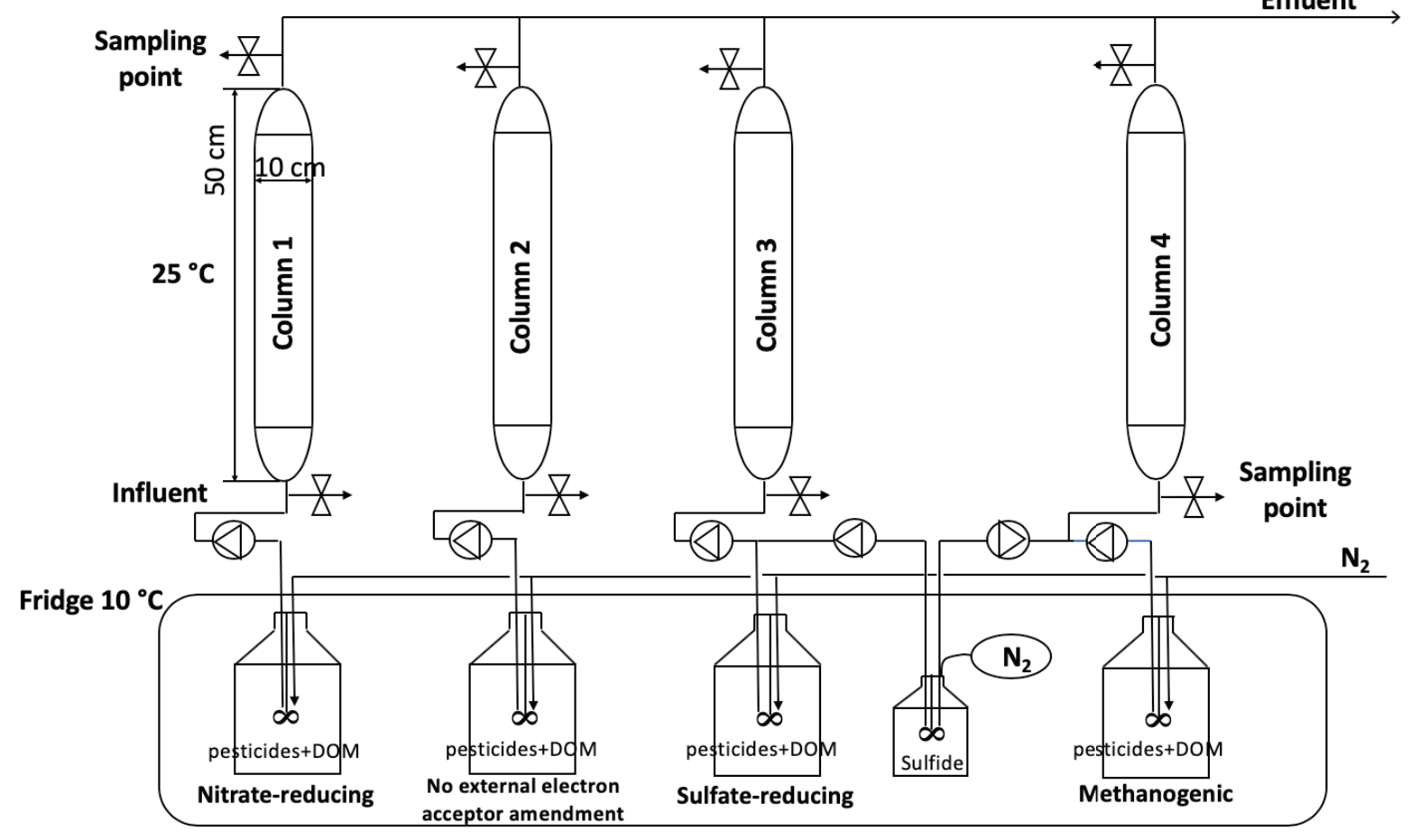

Figure 1. Column experimental setup simulating groundwater systems with different redox conditions. Column 1 was nitratereducing $\left(\mathrm{NO}_{3}{ }^{-}\right.$at $850 \mathrm{mg} / \mathrm{L}$ concentration), column 2 received no external electron acceptor amendment (run with only nutrients to make use of natural iron on the aquifer material), column 3 was sulfate-reducing ( $\mathrm{SO}_{4}^{2-}$ at $1190 \mathrm{mg} / \mathrm{L}$ concentration), and column 4 was methanogenic (run with sulfide amendment to obtain highly reducing conditions). The concentration of each pesticide (2,4-D, BAM, MCPP, and bentazone) was $1 \mathrm{mg} / \mathrm{L}$. The concentration of DOM was $10 \mathrm{mgC} / \mathrm{L}$. The column experiments lasted for 440 days and DOM was added at day 229. Media were flushed with $\mathrm{N}_{2}$.

The cylinder glass columns with $10 \mathrm{~cm}$ internal diameter and $50 \mathrm{~cm}$ length were packed with aquifer material collected from a location where drinking water is produced from groundwater. The aquifer material was low in organic matter content, $0.95 \pm 0.60 \%$ (detailed information is shown in Table S3) and retained in the columns by sintered glass filters placed in the bottom of the columns (pore size 40-100 $\mu \mathrm{m})$. The experimental set up was located in a cabinet with blue Plexiglas walls to prevent photodegradation of pesticides. Each column was fed with weekly-refreshed media with specific electron 
acceptor (Table S2). In each media, the concentration of each pesticide (2,4-D, BAM, MCPP, and bentazone) was $1 \mathrm{mg} / \mathrm{L}$. The media was placed in a fridge at $10^{\circ} \mathrm{C}$ to prevent a potential activity in the bottles, and was continuously stirred and purged with $\mathrm{N}_{2}$. The columns were at room temperature $25^{\circ} \mathrm{C}$ Media flow rate was around $12 \mathrm{~mL} / \mathrm{h}$. The experimental $\mathrm{pH}$ of Column 1, Column 2, Column 3, and Column 4 was $7.4,6.8,8.8$ and 8.4 respectively. 2,4-D (pKa=3.4), MCPP (pKa $=3.1)$, and bentazone $(\mathrm{pKa}=3.5)$ were in ionized form at the experimental $\mathrm{pH}$. Effluent and influent samples were collected for chemical analysis.

Column experiments lasted for 440 days. During the first 229 days, columns were run with only media, electron acceptors, and pesticides in order to determine the natural biodegradation capacity of the aquifer material microbial community under the different redox conditions. Thereafter, on day 229, DOM was added to the media in an attempt to stimulate pesticide biodegradation with a DOM concentration of $10 \mathrm{mgC} / \mathrm{L}$. Selection of DOMcompost for stimulation in column experiments was based on the results of microcosm experiments. Abiotic microcosm experiments were conducted with aquifer material to test the removal of pesticides due to any physical and chemical reactions.

\subsection{Sampling and analysing}

\subsubsection{Pesticides}

For microcosm experiments, pesticide removal rate in the microcosm bottles was calculated as the change in pesticide concentration between sampling time points. For column experiments, pesticide removal was calculated based on comparing the effluent concentration with influent concentration (pesticide concentration in the media upon media preparation). Samples were analysed twice per month. Samples were centrifuged for $10 \mathrm{~min}$ at $10,000 \mathrm{rpm}$ and stored at $-20^{\circ} \mathrm{C}$ before analysis. Pesticide concentration was measured by UPLC (ultimate 3000, Thermo, USA) with a diode array detector (DAD). UPLC was equipped with CSH phenyl-Hexyl column $(3.5 \mathrm{~mm}, 300 \AA, 0.1 \times 150 \mathrm{~mm})$. The mobile phase was a mixture of eluent A (water with $0.1 \%$ formic acid) and eluent B (acetonitrile with $0.1 \%$ formic acid) with a flow rate at $0.3 \mathrm{~mL} / \mathrm{min}$. The sample injection volume was $50 \mu \mathrm{l}$. The detection results were acquired and analysed by Xcalibur software. The detection limit is $0.02 \mathrm{mg} / \mathrm{L}$.

\subsubsection{Electron acceptor analysis}

Samples for electron acceptor analysis were tested monthly. Samples for nitrate and sulfate were pretreated by centrifugation for $10 \mathrm{~min}$ at $10,000 \mathrm{rpm}$ and stored at $-20^{\circ} \mathrm{C}$ before analysis. Nitrate and sulfate were measured by ion chromatography (Dionex ICS 2100, USA). Iron (II) was measured using Dr. Lange test kits (Hach Lange $\mathrm{GmbH}$, Germany) on a Hach DR/3900 spectrophotometer. Iron (II) was 
immediately analysed after sampling to prevent oxidation of Iron (II) to Iron (III). Methane was not measured since minimal pesticide biodegradation was found in the methanogenic column.

\subsubsection{DOM quantification and fractionation}

For the microcosm experiments, samples for DOM quantification and fractionation were taken at the beginning and the end of the experiments. For column experiments, samples were taken from influent and effluent at day 405 and day 412, respectively. The changes in DOM fractions during microcosm and column experiments were analysed and related to pesticide biodegradation. DOM was fractionated according to a batch fractionation procedure at the following compound-class level: humic acids (HA), fulvic acids (FA), hydrophilic acids (Hy), and hydrophobic neutrals (HoN) (van Zomeren and Comans, 2007). First, the total DOM sample was acidified to $\mathrm{pH} 1$ with $6 \mathrm{M} \mathrm{HCl}$ and allowed to stand overnight. The acidified solution was then centrifuged (15 min, $3500 \mathrm{rpm}$ ), separating the HA from the supernatant containing FA + HoN + Hy. Next, the HA pellet was re-dissolved in $0.1 \mathrm{M} \mathrm{KOH}(\mathrm{pH} 12)$. Subsequently, the resin DAX-8 (Sigma-Aldrich) was added to the supernatant in a 1:10 resin to solution ratio. FA and HoN pools were then bound to the resin during $1 \mathrm{~h}$ horizontal shaking. The Hy pool was then separated from FA and HoN pools. Finally, the resin with adsorbed FA and HoN was washed twice with $0.1 \mathrm{M} \mathrm{KOH}$ to re-dissolve FA. The concentrations of HA, FA, Hy were measured directly by a Sievers ${ }^{\mathrm{TM}} 900$ Series TOC Analyser (GE Analytical Instrument, USA), and the concentration of HoN was calculated by subtracting the concentration of FA and HoN from the supernatant containing FA + HoN and Hy. The DOM recovery of the fractionation procedure was $98-100.25 \%$.

\subsubsection{DNA extraction and qPCR}

Microbial abundance and functional genes in the columns were analysed and compared before DOM addition (day 180) and after DOM addition (day 250 and day 370). Aquifer solid samples ( $2.5 \mathrm{~g})$ were taken from the top of the columns. The liquid effluent samples ( $150 \mathrm{ml})$ were filtered on a $0.22 \mathrm{um}$ filter (Millipore, Ireland). MoBio PowerSoil ${ }^{\circledR}$ DNA Isolation Kits were used for DNA extraction according to manufacturer's recommendations. The filters, containing microbes, were cut in pieces and put in the power bead tubes. For the aquifer samples, 2 grams of solid were used and divided over four power bead tubes; the DNA was subsequently pooled on the filter prior to elution. DNA concentration and purity were quantified on a Nanodrop spectrophotometer (The DeNovix DS-11 FX series) with OD260/OD280 and then stored at -20 C. Quantitative PCR ( $(\mathrm{PPCR}$ ) analysis was used to quantify total bacteria based on the 16S rRNA gene, functional gene $t f d A$ involved in the biodegradation of 2,4-D (Bælum et al., 2008), and other functional genes involved in nitrate (nirS, nirk, nosZ) (Throbäck et al., 2004) and sulfate reduction $(d s r B)$ related to redox conditions (Müller et al., 2015). Analysis was performed on an iQ SYBR Green 
using Bio-Rad super mix using CFX384 Touch $^{\text {TM }}$ Real-Time PCR Detection System. All qPCR assays were performed in triplicate with a total volume of $10 \mu \mathrm{L}$ reactions. Gene copy numbers from the results of qPCR were calculated as copies/ml sample, while for solids, the sample was calculated as copies/gram of aquifer material. Detailed information for qPCR primers and amplification protocols can be found in Table S4.

\section{Results and discussion}

\subsection{Microcosm experiments}

No pesticide removal was observed in abiotic control experiments. In biotic experimental setups (without DOM addition, and with DOMcompost or DOMGw addition), 2,4-D degradation rate increased with incubation time (Figure 2A), indicating a further enrichment of 2,4-D biodegrading microorganisms. Furthermore, degradation was promoted in the presence of DOM, and the highest 2,4-D degradation rate was obtained with DOM compost. At day 14, for instance, the degradation rate in the presence of DOMcompost was 1.3 fold increase compared with in the presence of DOMGW and 1.5 fold increase compared with in the absence of DOM.

Under oligotrophic conditions, DOM can act as a carbon and energy source in addition to pesticides to support microbial growth (Bowen et al., 2009; Horemans et al., 2017; Wiedemeier, 1999), or act as a limiting substrate for co-metabolic biodegradation of pesticides (Dalton et al., 1982; Marschner and Kalbitz, 2003; Wiedemeier, 1999). Moreover, due to the structural similarities between DOM and pesticides, DOM can function as a structural analogue, stimulating the production of enzymes that can subsequently be used for pesticide biodegradation (Aleksieva et al., 2002; Hoppe-Jones et al., 2012; Kim and Hao, 1999). Research has shown that biodegradation of pesticides can be stimulated by artificially adding carbon substrates (Harris, 1967; Horvath, 1973; McCormick and Hiltbold, 1966; Roeth et al., 1969; Semprini, 1997). More recent research also showed the addition of DOM promotes the removal of emerging trace organic chemicals in managed aquifer recharge systems (Hoppe-Jones et al., 2012; Maeng et al., 2011; Rauch-Williams et al., 2010). Since 2,4-D was also rapidly degraded without DOM addition, it is possible that DOM served as a supplemental carbon and energy source for 2,4-D biodegradation, or DOM might stimulate gene expression. The increased 2,4-D degradation rate could be due to increased microbial activity, as was observed by the increased $\mathrm{O}_{2}$ consumption in the presence of DOM (Table S5). 

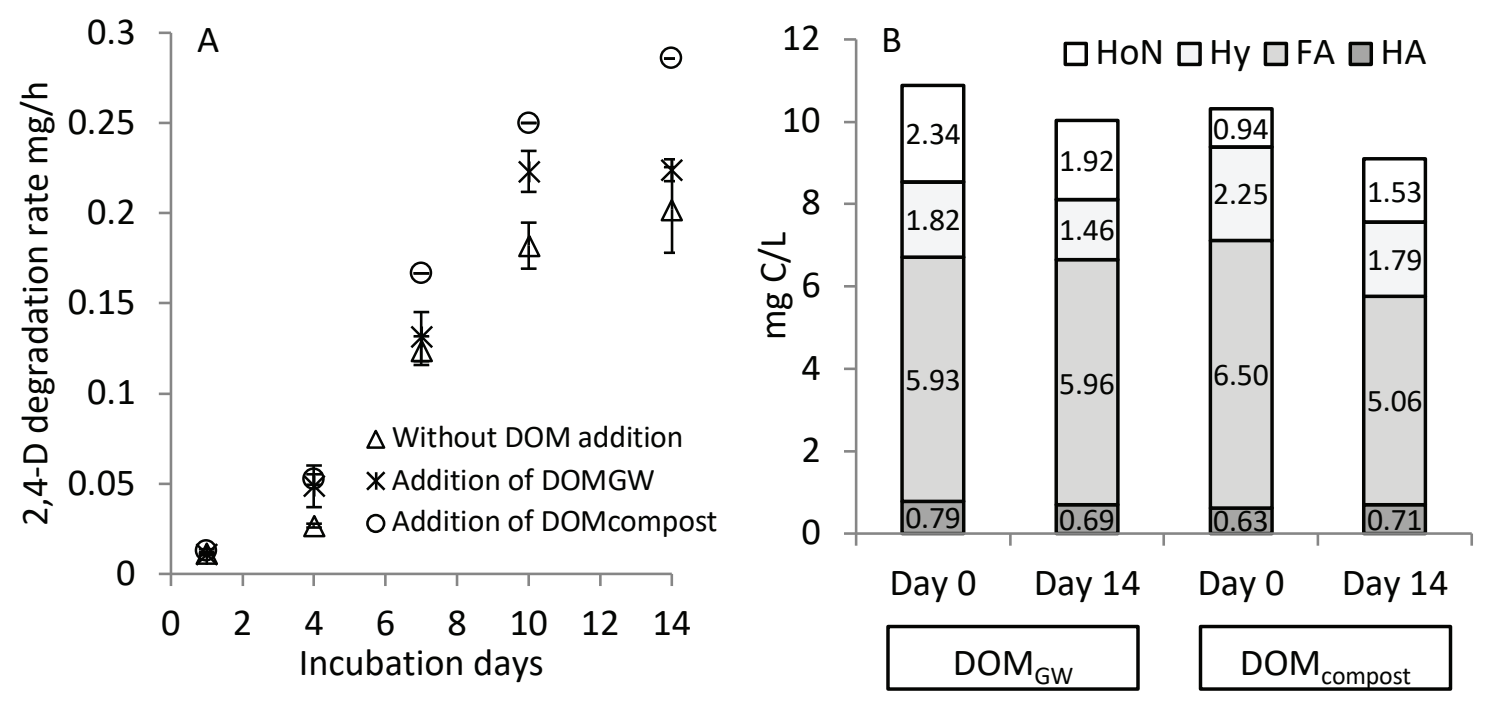

Figure 2. Results of microcosm experiments investigating the influence of different DOM sources on 2,4-D biodegradation. The experiments lasted for 14 days. (A) Influence of DOM on 2,4-D biodegradation rate under aerobic conditions; results were average degradation rate of triplicate microcosm experiments with standard deviation. (B) changes in DOMGW and DOMcompost fractions before and after 2,4-D biodegradation. DOMGW was extracted from natural groundwater; DOMcompost was extracted from compost with a composition of 50\% screened wood, $25 \%$ grass litter, and $25 \%$ leaf litter. Humic acids (HA), fulvic acids (FA), hydrophilic acids (Hy), and hydrophobic neutrals (HoN) were fractionated from total DOMGw/DOMcompost.

DOM fractionation was performed to ascertain the influence of biological activity on DOM composition (Figure $2 \mathrm{~B}$ ). Changes in $\mathrm{DOM}_{\mathrm{GW}}$ fractions were not as obvious as changes in DOM $\mathrm{M}_{\text {compost }}$ fractions, where a decrease in particularly the FA fraction was observed over the course of the experiment. This result indicates that DOMcompost was more actively degraded, suggesting degradable DOM can support higher 2,4-D biodegradation rates. DOM structure, composition, and biodegradability are highly variable and dependent on the DOM source (Leenheer and Croué, 2003), which is also reflected in recent molecular analyses of the supramolecular HA and FA fractions isolated from different origins (Schellekens et al., 2017). DOMGw is relatively more recalcitrant to biodegradation than DOMcompost, since the more easily metabolized components of DOMGW would have already been utilized during soil passage before entering the deep groundwater system from which it was isolated. In contrast, DOMcompost contains fresh organic matter which can be easily utilized by microorganisms (Straathof and Comans, 2015). The microcosm experiments proved that DOM had the potential to stimulate pesticide biodegradation under aerobic condition. This conclusion resulted in the decision to study if DOM can also stimulate pesticide biodegradation under anaerobic conditions typical for groundwater systems. Therefore, DOM compost was selected for use in the column experiments to further investigate stimulated pesticide biodegradation.

\subsection{Simulated groundwater systems}

\subsubsection{Pesticide biodegradation}


The natural degradation capacity of aquifer material, as it relates to redox conditions and the influence of DOM on pesticide biodegradation, was investigated by column experiments under different redox conditions that more closely resembled actual groundwater systems. The results of abiotic microcosm experiments suggest that biotic transformation of pesticides was the main mechanism for pesticide removal in the simulated groundwater systems, since little changes in pesticide concentration were observed in abiotic controls during the incubation time (Figure S1). Before DOM addition, minimal biodegradation of BAM, MCPP, and bentazone was observed under all four conditions (Table 1). Some natural attenuation (Day 0-228) of 2,4-D was observed under nitrate-reducing condition (Column 1), with an average removal efficiency of $23.5 \%$. In addition, no significant consumption of electron acceptors $\mathrm{NO}_{3}{ }^{-}$and $\mathrm{SO}_{4}{ }^{2-}$ was observed. Together, these results indicate that the natural aquifer material from this drinking water production location has a limited degradation activity for the selected four pesticides under the given redox conditions.

Table 1. Pesticide removal and electron acceptor consumptions in simulated groundwater systems under different redox conditions. DOMcompost was added to each column at day 229. Averages and standard deviations were calculated from samples measured every month. NA: not applicable

\begin{tabular}{|c|c|c|c|c|c|}
\hline & \multirow[b]{2}{*}{ Incubation days } & \multicolumn{4}{|c|}{ Removal efficiency \% } \\
\hline & & $\begin{array}{l}\text { Nitrate- } \\
\text { reducing } \\
\text { (Column 1) }\end{array}$ & $\begin{array}{l}\text { No electron } \\
\text { acceptor } \\
\text { amendment } \\
\text { (Column 2) }\end{array}$ & $\begin{array}{l}\text { Sulfate- } \\
\text { reducing } \\
\text { (Column 3) }\end{array}$ & $\begin{array}{c}\text { Methanogenic } \\
\text { (Column 4) }\end{array}$ \\
\hline \multirow{2}{*}{$2,4-D$} & Day 0 to day 228 & $23.5 \pm 10.2$ & $-6.3 \pm 12.6$ & $-2.0 \pm 4.6$ & $9.8 \pm 15.6$ \\
\hline & Day 229 to day 440 & $82.3 \pm 11.6^{*}$ & $31.1 \pm 36.3^{*}$ & $44.4 \pm 37.2^{*}$ & $14.7 \pm 9.5$ \\
\hline \multirow{2}{*}{ MCPP } & Day 0 to day 228 & $2.5 \pm 9.6$ & $-14.8 \pm 8.5$ & $-2.9 \pm 14.6$ & $-3.5 \pm 8.9$ \\
\hline & Day 229 to day 440 & $4.1 \pm 9.2$ & $1.8 \pm 8.5$ & $9.3 \pm 10.2$ & $9.3 \pm 6.2$ \\
\hline \multirow{2}{*}{ BAM } & Day 0 to day 228 & $2.9 \pm 26.2$ & $-11.5 \pm 23.0$ & $-4.7 \pm 7.6$ & $-5.9 \pm 7.9$ \\
\hline & Day 229 to day 440 & $4.0 \pm 13.8$ & $-0.9 \pm 12.4$ & $15.0 \pm 14.5$ & $12.6 \pm 8.7$ \\
\hline \multirow{2}{*}{ Bentazone } & Day 0 to day 228 & $8.4 \pm 10.5$ & $-13.3 \pm 15.5$ & $-4.4 \pm 10.5$ & $-7.4 \pm 10.9$ \\
\hline & Day 229 to day 440 & $5.4 \pm 10.7$ & $3.4 \pm 9.3$ & $6.5 \pm 10.0$ & $12.0 \pm 7.6$ \\
\hline \multirow{2}{*}{$\begin{array}{l}\text { Electron } \\
\text { acceptor }\end{array}$} & Day 0 to day 228 & $3.3 \pm 4.2$ & NA & $4.1 \pm 14.4$ & NA \\
\hline & Day 229 to day 440 & $29.9 \pm 17.5$ & NA & $2.8 \pm 4.5$ & NA \\
\hline
\end{tabular}

*: DOM enhanced the biodegradation of 2,4-D.

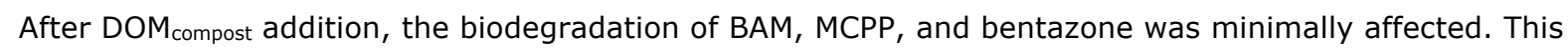
could be due to the lack of microbial degraders for BAM, MCPP, and bentazone in the aquifer material. Also, the property of the compounds may play a role (see Table S1). In contrast, 2,4-D degradation was observed under three different redox conditions. The removal efficiency of 2,4-D under nitrate-reducing condition (Column 1) was promoted within one week after DOM addition (point degradation data is shown in Figure S2). Additionally, a significant increase in $\mathrm{NO}_{3}{ }^{-}$consumption was also observed, from 

fractionation of the influent and effluent samples of Column 1 indicates a depletion of especially FA and consumption of total DOM (Figure 3). FA and Hy were the main reduced fractions, and this pattern was similar to our findings in the microcosm experiments.

280

This nearly instantaneous increase in degradation activity following DOM addition is notable. This result suggests that sufficient degradation capacity was present prior to DOM addition, but that the availability of a degradable carbon substrate was limiting microbial activity. From a technological standpoint, this result suggests that amendment with degradable DOM and $\mathrm{NO}_{3}^{-}$may be sufficient to stimulate 2,4-D biodegradation by aquifer indigenous microbial communities.

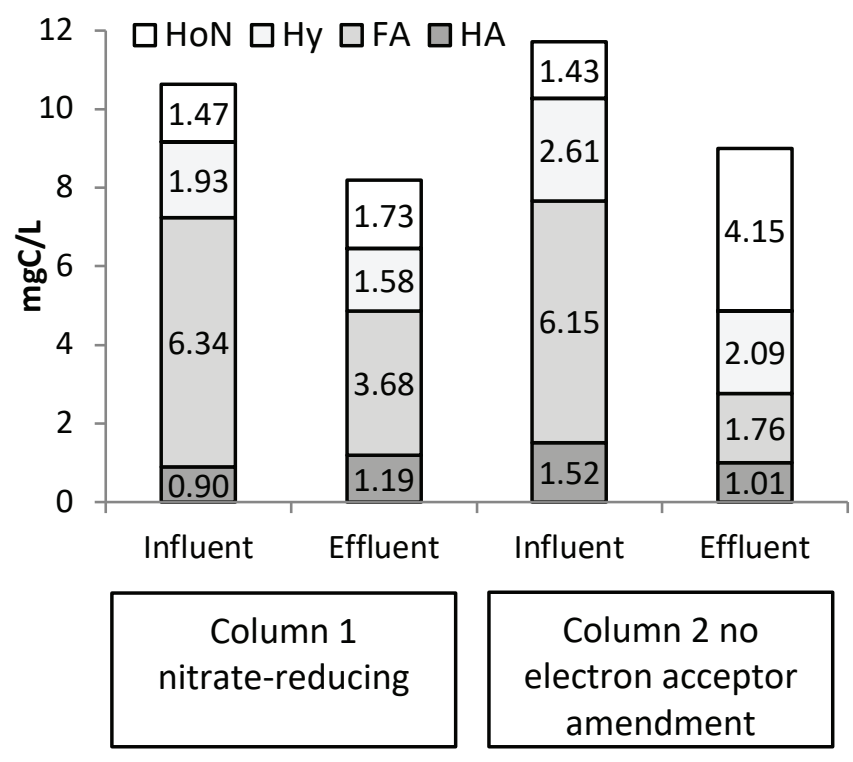

Figure 3. Changes in DOMcompost fractions before and after pesticide biodegradation under nitrate-reducing and no electron acceptor amendment conditions. 2,4-D degradation was observed in the Column 1 and Column 2. Humic acids (HA), fulvic acids (FA), hydrophilic acids (Hy), and hydrophobic neutrals ( $\mathrm{HoN})$ were fractionated from total DOM compost.

Notably, 2,4-D biodegradation was also stimulated without the addition of an electron acceptor (Column 2) after DOM addition. The biodegradation of 2,4-D was delayed as compared to the nitrate-reducing column, with a lag phase of around 100 days following the initial DOM amendment. It is hypothesized that iron naturally present in aquifer material contributed to 2,4-D biodegradation and that DOM may have acted as electron shuttles to enhance 2,4-D biodegradation. Previously reported research showed that the presence of humic substances that contained quinone moieties enhanced the anaerobic biodegradaton of benzene in incubation of iron (III)-reducing sediments, because humic substances could act as electron shuttles transfering electrons from reduced organics to iron (III) (Coates et al., 1998; Lovley, 2000; Lovley et al., 1996). However, no iron (II) was observed in the effluents of our 
columns. It is possible that there was iron in the aquifer soils, but we could not detect iron (II) in the effluent due to low concentration or iron precipitation in the column.

Conversely, an additional explanation is that DOM itself acts as an electron acceptor. Several studies have proved that humic substances (HA, FA) can act as terminal electron acceptors in anaerobic microbial oxidation of organic compounds (Benz et al., 1998; Lovley et al., 1996; Scott et al., 1998). Quinone moieties as well as other redox-active functional groups in DOM play an important role in the microbial reduction of DOM (Aeschbacher et al., 2009; Aeschbacher et al., 2011; Lovley et al., 1996; Newman and Kolter, 2000; Nurmi and Tratnyek, 2002; Scott et al., 1998). Klüpfel et al. have reported that humic susbstances were biologically reduced in growth media containing the electron donor lactate, and the reduced humic substances could be re-oxidized in the presence of oxygen (Klüpfel et al., 2014). This theory is further supported by the fact that changes in DOM fractions and DOM consumption were observed in Column 2, where no external electron accetpors were added. The results of DOM fractionations (Figure 3) show a reduction of FA pool from $53 \%$ to $19 \%$ in the column without external electron acceptor amendment, indicating that FA pool of DOM compost might contain quinone moieties or other redox-active functional groups, and act as electron acceptors or electron shuttles in 2,4-D biodegradation.

Regardless of the role of DOM, the results overall provide important insight into the stimulation of 2,4-D biodegradation. DOM alone can stimulate 2,4-D biodegradation without further amendment of additional electron acceptors. This result indicates that under field conditions, biostimulation with natural humic substances is sufficient to support in situ bioremediation. Further research is required to identify their specific functioning and molecular features that facilitate pesticide degradation.

Under sulfate-reducing conditions (Column 3), 2,4-D was degraded after DOM addition; however, the degradation of 2,4-D actually occurred in the media instead of in the column (2,4-D concentration decreased from $1 \mathrm{mg} / \mathrm{L}$ to $0 \mathrm{mg} / \mathrm{L}$ in the media within 7 days). Meanwhile, no $\mathrm{SO}_{4}{ }^{2-}$ consumption was found in the column 3 (Table 1 ). We hypothesize that $2,4-D$ in the media could be degraded by the microorganisms introduced by DOM addition, since $0.45 \mu \mathrm{m}$ filters were used when we did DOMcompost extraction and small microbes in the compost were not removed by $0.45 \mu \mathrm{m}$ filters. Therefore, a microcosm test was performed to check the biotic and abiotic transformation of 2,4-D in sulfate-reducing media. However, no degradation of 2,4-D was observed (data not shown). The reasons for the elimination of 2,4-D in media are still unknown. Under methanogenic conditions (Column 4), DOM addition had no significant effect on 2,4-D biodegradation.

\subsubsection{Microbial abundance and functional genes}


Quantitative PCR analysis show that the functional genes for denitrifying bacteria (nirK, nirS, nosZ) and sulfate reducing bacteria ( $d s r B$ ) were found under all of the applied redox conditions (Figure S3). The $d s r B$ genes were most abundant in the sulfate-reducing column, suggesting enrichment of sulfatereducers under sulfate-reducing conditions. In the nitrate-reducing column, there was no significant enrichment of denitrifying bacteria despite the significant consumption of $\mathrm{NO}_{3}{ }^{-}$observed after DOM addition.

No increase in microbial population as assessed by the bacterial 16S rRNA gene was observed in the solid phase samples from the nitrite-reducing column (Column 1) and column without electron acceptor amendment (Column 2; Figure 4 and S3). However an increase in total bacterial and archaeal 16S rRNA gene and functional genes after DOM addition was observed in the liquid phase of all columns (Figure 4 and Figure S3). This suggests microbial growth due to DOM addition, but that this biomass was mostly washed-out in the liquid phase. This increase in overall biomass supports the hypothesis that microbial activity was limited by the availability of a carbon substrate in the organic carbon poor aquifer solids.

The functional gene $t f d A$ responsible for 2,4-D degradation was found in all columns, and was slightly enriched in the liquid samples following DOM addition, indicating washout of biodegradation capacity. Increased abundance of $t f d A$ genes in all columns suggest that the addition of DOM supported the growth of the bacteria carrying $t f d A$ genes. It should be pointed out that $t f d A$ genes have been known to produce a-ketoglutarate-dependent 2,4-D dioxygenase that initiate the degradation of 2,4-D to 2,4dichlorophenol by removing the acetate chain under aerobic conditions (de Lipthay et al., 2002). However, $t f d A$ genes in our study were detected in anaerobic column systems. It was also possible that the $t f d A$ genes could exist in a facultative microorganism, which could live in both aerobic and anaerobic conditions. In nitrite-reducing column (Column 1) and the column without electron acceptor amendment (Column 2), tfdA genes could be responsible for 2,4-D reduction. However, the fact that many 2,4-D degrading bacteria do not carry $t f d A$ genes and many bacteria carrying $t f d A$ genes do not have the ability to degrade 2,4-D highlights the need for more comprehensive studies into the microbial ecology of 
A

1. $0 \mathrm{E}+10$

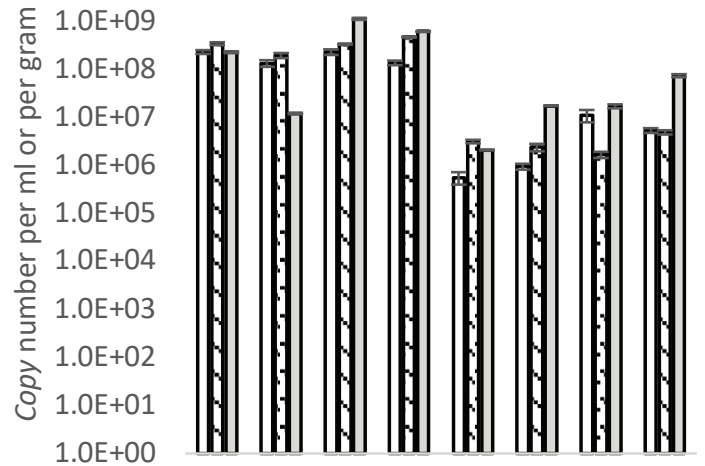

$1.0 \mathrm{E}+00$

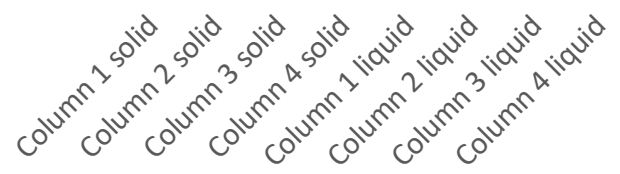

B

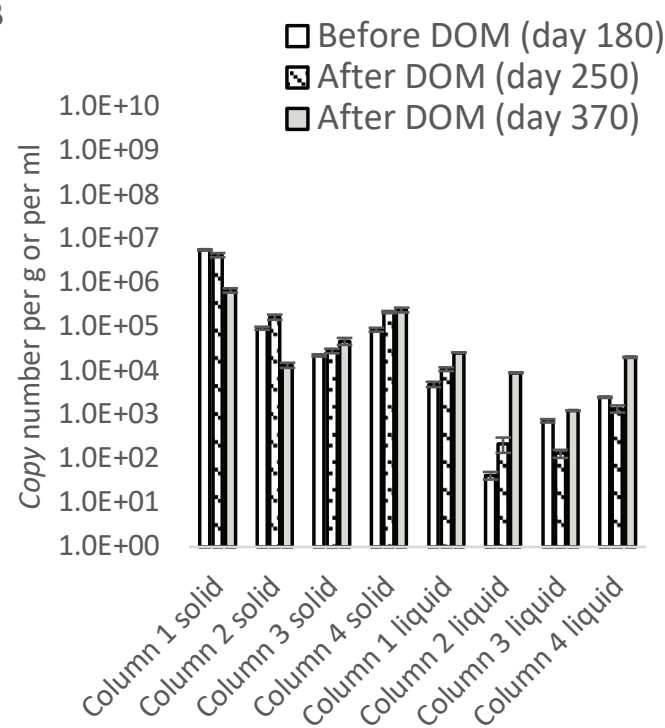

Figure 4. GPCR of (A) total bacterial 16S rRNA gene and (B) tfdA gene in columns before DOM addition (day 180) and after DOM addition (day 250 and day 370). Copy numbers were average of triplicate qPCR measurements and error bars were the standard deviation thereof. Column 1 was nitrate-reducing; Column 2 was no electron acceptor amendment; Column 3 was sulfate-reducing; Column 4 was methanogenic. All qPCR results were the average of triplicate assays with standard deviation.

\section{Conclusions}

The results of this work provide new insights into the biodegradation of four pesticides in actual groundwater systems in relation to electron acceptor and DOM availability. Pesticides 2,4dichlorophenoxyacetic acid (2,4-D), 2,6-dichlorobenzamide (BAM), mecoprop-p (MCPP) and bentazone were tested. The biodegradation of BAM, MCPP and bentazone was minimally affected by the presence of DOM, while the degradation of 2,4-D was substantially promoted after DOM addition. Column experiments with aquifer solids have shown that DOM amendment without electron acceptor addition can support biodegradation, while the observed specific depletion of the fulvic acid (FA) fraction of DOM may be indicative for its functioning as electron acceptors or electron shuttles in 2,4-D biodegradation. This work suggests that the addition of suitable DOM could be further developed towards an in-situ technology for biostimulation of pesticide removal in groundwater. These findings highlight the need for further research into the molecular properties by which DOM stimulates pesticide biodegradation, with specific attention to redox-active functional groups, and the molecular ecology of anaerobic pesticide biodegradation. This study has provided an important proof-of-principle that DOM can support pesticide biodegradation with specific suggestions for follow-up research, as crucial step towards the realization of in-situ technologies to safeguard drinking water quality.

All authors have no competing interests. 
Mallin, Robin Meijer, Aken Puti Wanguyun, and Michael Lim for research assistance, and Gerlinde Vink

\section{Reference}

Aeschbacher M, Sander M, Schwarzenbach RP. Novel electrochemical approach to assess the redox properties of humic substances. Environmental science \& technology 2009; 44: 87-93.

Aeschbacher M, Vergari D, Schwarzenbach RP, Sander M. Electrochemical analysis of proton and electron transfer equilibria of the reducible moieties in humic acids. Environmental science \& technology 2011; 45: 8385-8394.

Aislabie J, Lloyd-Jones G. A review of bacterial-degradation of pesticides. Soil Research 1995; 33: 925-942.

Aleksieva Z, Ivanova D, Godjevargova T, Atanasov B. Degradation of some phenol derivatives by Trichosporon cutaneum R57. Process Biochemistry 2002; 37: 1215-1219.

Bælum J, Nicolaisen MH, Holben WE, Strobel BW, Sørensen J, Jacobsen CS. Direct analysis of tfdA gene expression by indigenous bacteria in phenoxy acid amended agricultural soil. Isme Journal 2008; 2 : 677-687.

Barbash JE, Thelin GP, Kolpin DW, Gilliom RJ. Major Herbicides in Ground Water. Journal of Environmental Quality $2001 ; 30: 831-845$.

Barbieri M, Carrera J, Sanchez-Vila X, Ayora C, Cama J, Köck-Schulmeyer M, et al. Microcosm experiments to control anaerobic redox conditions when studying the fate of organic micropollutants in aquifer material. Journal of Contaminant Hydrology 2011; 126: 330-345.

Benz M, Schink B, Brune A. Humic acid reduction by Propionibacterium freudenreichii and other fermenting bacteria. Applied and environmental microbiology 1998; 64: 4507-4512.

Boopathy R. Factors limiting bioremediation technologies. Bioresource technology 2000; 74: 63-67.

Bowen SR, Gregorich EG, Hopkins DW. Biochemical properties and biodegradation of dissolved organic matter from soils. Biology and fertility of soils 2009; 45: 733-742.

Coates JD, Ellis DJ, Blunt-Harris EL, Gaw CV, Roden EE, Lovley DR. Recovery of humic-reducing bacteria from a diversity of environments. Applied and environmental microbiology 1998; 64: 1504-1509.

Dalton H, Stirling D, Quayle J. Co-metabolism [and discussion]. Philosophical Transactions of the Royal Society of London B: Biological Sciences 1982; 297: 481-496.

De A, Bose R, Kumar A, Mozumdar S. Targeted delivery of pesticides using biodegradable polymeric nanoparticles: Springer, 2014.

de Lipthay JR, Aamand J, Barkay T. Expression of tfdA genes in aquatic microbial communities during acclimation to 2, 4-dichlorophenoxyacetic acid. FEMS microbiology ecology 2002; 40: 205-214.

Dec J, Shuttleworth K, Bollag J-M. Microbial release of 2, 4-dichlorophenol bound to humic acid or incorporated during humification. Journal of environmental quality 1990; 19: 546-551.

Delgado-Moreno L, Nogales R, Romero E. Biodegradation of high doses of commercial pesticide products in pilot-scale biobeds using olive-oil agroindustry wastes. Journal of Environmental Management 2017; 204: 160 .

Egli T. How to live at very low substrate concentration. water research 2010; 44: 4826-4837.

EU. Directive 2006/118/EC of the European Parliament and the Council of 12th of December 2006 on the protection of groundwater against pollution and deterioration. 2006.

Fenner K, Canonica S, Wackett LP, Elsner M. Evaluating pesticide degradation in the environment: blind spots and emerging opportunities. Science 2013; 341: 752-758.

Greskowiak J, Hamann E, Burke V, Massmann G. The uncertainty of biodegradation rate constants of emerging organic compounds in soil and groundwater - A compilation of literature values for 82 substances. Water Research 2017; 126: 122-133.

Harris CI. DECOMPOSITION IN SOIL Fate of 2-chloro-s-triazine herbicides in soil. Journal of Agricultural and Food Chemistry 1967; 15: 157-162.

Helbling DE. Bioremediation of pesticide-contaminated water resources: the challenge of low concentrations. Current opinion in biotechnology 2015; 33: 142-148.

Hogan D, Buckley D, Nakatsu C, Schmidt T, Hausinger R. Distribution of the tfdA gene in soil bacteria that do not degrade 2, 4-dichlorophenoxyacetic acid (2, 4-D). Microbial ecology 1997; 34: 90-96.

Hoppe-Jones C, Dickenson ER, Drewes JE. The role of microbial adaptation and biodegradable dissolved organic carbon on the attenuation of trace organic chemicals during groundwater recharge. Science of the Total Environment 2012; 437: 137-144.

Horemans B, Raes B, Vandermaesen J, Simanjuntak Y, Brocatus H, T'Syen J, et al. Biocarriers improve bioaugmentation efficiency of a rapid sand filter for the treatment of 2,6-dichlorobenzamide (BAM)contaminated drinking water. Environmental Science \& Technology 2017; 51: 1616. 
Horemans B, Vandermaesen J, Vanhaecke L, Smolders E, Springael D. Variovorax sp.-mediated biodegradation of the phenyl urea herbicide linuron at micropollutant concentrations and effects of natural dissolved organic matter as supplementary carbon source. Applied Microbiology \& Biotechnology 2013; 97 : 9837-46.

Horvath R. Enhancement of co-metabolism of chlorobenzoates by the co-substrate enrichment technique. Applied microbiology 1973; 25: 961-963.

Jurado A, Walther M, Díaz-Cruz S. Occurrence, fate and environmental risk assessment of the organic microcontaminants included in the Watch Lists set by EU Decisions 2015/495 and 2018/840 in the groundwater of Spain. Science of The Total Environment 2019.

$\mathrm{Kim} \mathrm{MH}$, Hao OJ. Cometabolic degradation of chlorophenols by Acinetobacter species. Water Research 1999; 33: 562-574.

Klüpfel L, Piepenbrock A, Kappler A, Sander M. Humic substances as fully regenerable electron acceptors in recurrently anoxic environments. Nature Geoscience 2014; 7: 195.

Lee H-J, Kim KY, Hamm S-Y, Kim M, Kim HK, Oh J-E. Occurrence and distribution of pharmaceutical and personal care products, artificial sweeteners, and pesticides in groundwater from an agricultural area in Korea. Science of The Total Environment 2019; 659: 168-176.

Leenheer J, Croué J. Aquatic organic matter: understanding the unknown structures is key to better treatment of drinking water. Environ. Sci. Technol 2003; 1: 19.

Loos R, Locoro G, Comero S, Contini S, Schwesig D, Werres F, et al. Pan-European survey on the occurrence of selected polar organic persistent pollutants in ground water. Water Research 2010; 44: 4115-4126.

Lovley DR. Anaerobic benzene degradation. Biodegradation 2000; 11: 107-116.

Lovley DR, Coates JD, Blunt-Harris EL, Phillips EJ, Woodward JC. Humic substances as electron acceptors for microbial respiration. Nature 1996; 382: 445.

Maeng SK, Sharma SK, Lekkerkerker-Teunissen K, Amy GL. Occurrence and fate of bulk organic matter and pharmaceutically active compounds in managed aquifer recharge: a review. Water research 2011; 45: 3015-3033.

Marschner B, Kalbitz K. Controls of bioavailability and biodegradability of dissolved organic matter in soils. Geoderma 2003; 113: 211-235.

McCormick LL, Hiltbold A. Microbiological decomposition of atrazine and diuron in soil. Weeds 1966: 77-82.

Meffe R, de Bustamante I. Emerging organic contaminants in surface water and groundwater: a first overview of the situation in Italy. Science of the Total Environment 2014; 481: 280-295.

Müller AL, Kjeldsen KU, Rattei T, Pester M, Loy A. Phylogenetic and environmental diversity of DsrAB-type dissimilatory (bi)sulfite reductases. Isme Journal 2015; 9: 1152.

Newman DK, Kolter R. A role for excreted quinones in extracellular electron transfer. Nature 2000; $405: 94$

Nurmi JT, Tratnyek PG. Electrochemical properties of natural organic matter (NOM), fractions of NOM, and model biogeochemical electron shuttles. Environmental science \& technology 2002; 36: 617-624.

Odukkathil G, Vasudevan N. Toxicity and bioremediation of pesticides in agricultural soil. Reviews in Environmental Science and Bio/Technology 2013; 12: 421-444.

Pinoherrera DO, Pechaud Y, Huguenot D, Esposito G, van Hullebusch ED, Oturan MA. Removal mechanisms in aerobic slurry bioreactors for remediation of soils and sediments polluted with hydrophobic organic compounds: An overview. Journal of Hazardous Materials 2017; 339: 427.

Rauch-Williams T, Hoppe-Jones C, Drewes J. The role of organic matter in the removal of emerging trace organic chemicals during managed aquifer recharge. Water research 2010; 44: 449-460.

Robles-González IV, Fava F, Poggi-Varaldo HM. A review on slurry bioreactors for bioremediation of soils and sediments. Microbial Cell Factories,7,1(2008-02-29) 2008; 7: 5.

Roeth FW, Lavy T, Burnside O. Atrazine degradation in two soil profiles. Weed Science 1969: 202-205.

Schellekens J, Buurman P, Kalbitz K, Zomeren AV, Vidaltorrado P, Cerli C, et al. Molecular Features of Humic Acids and Fulvic Acids from Contrasting Environments. Environmental Science \& Technology 2017; 51.

Scott DT, McKnight DM, Blunt-Harris EL, Kolesar SE, Lovley DR. Quinone moieties act as electron acceptors in the reduction of humic substances by humics-reducing microorganisms. Environmental Science \& Technology 1998; 32: 2984-2989.

Semprini L. Strategies for the aerobic co-metabolism of chlorinated solvents. Current Opinion in Biotechnology 1997; 8: 296-308.

Squillace PJ, Scott JC, Moran MJ, Nolan B, Kolpin DW. VOCs, pesticides, nitrate, and their mixtures in groundwater used for drinking water in the United States. Environmental science \& technology 2002; 36: 1923-1930.

Straathof $\mathrm{AL}$, Comans RN. Input materials and processing conditions control compost dissolved organic carbon quality. Bioresource technology 2015; 179: 619-623.

Stuart M, Manamsa K, Talbot J, Crane E. Emerging contaminants in groundwater. 2011.

Sutton R, Sposito G. Molecular structure in soil humic substances: the new view. Environmental Science \& Technology 2005; 39: 9009-9015.

Swartjes F, van der Linden A, van der Aa N. Bestrijdingsmiddelen in grondwater bij drinkwaterwinningen: huidige belasting en mogelijke maatregelen. RIVM rapport 2016-0083 2016.

Throbäck IN, Enwall K, Jarvis A, Sa, Hallin S. Reassessing PCR primers targeting nirS, nirK and nosZ genes for community surveys of denitrifying bacteria with DGGE, 2004.

Thuy PT, Van Geluwe S, Nguyen V-A, Van der Bruggen B. Current pesticide practices and environmental issues in Vietnam: management challenges for sustainable use of pesticides for tropical crops in (South-East) Asia to avoid environmental pollution. Journal of Material Cycles and Waste Management 2012; 14: 379-387.

van Zomeren A, Comans RN. Measurement of humic and fulvic acid concentrations and dissolution properties by a rapid batch procedure. Environmental science \& technology 2007; 41: 6755-6761. 
Vryzas Z, Papadakis EN, Vassiliou G, Papadopoulou-Mourkidou E. Occurrence of pesticides in transboundary aquifers of North-eastern Greece. Science of the Total Environment 2012; 441: 41-48.

Wiedemeier TH. Natural attenuation of fuels and chlorinated solvents in the subsurface: John Wiley \& Sons, 1999.

Willems HP, Lewis K, Dyson J, Lewis F. Mineralization of 2, 4-D and atrazine in the unsaturated zone of a sandy loam soil. Soil Biology and Biochemistry 1996; 28: 989-996.

Znad H, Ohata H, Tade MO. A net draft tube slurry airlift bioreactor for 2,4-D (2,4-dichlorophenoxyacetic acid) pesticide biodegradation. Canadian Journal of Chemical Engineering 2010; 88: 565-573. 


\section{Supporting Information}

Influence of Different Redox Conditions and Dissolved Organic Matter on Pesticide Biodegradation in Simulated Groundwater Systems

Authors: Yujia Luo ${ }^{a}$ Siavash Atashgahib, Huub H.M. Rijnaartsa, Rob N.J. Comans ${ }^{c}$, Nora B. Sutton ${ }^{a}$

a Sub-department of Environmental Technology, Wageningen University \& Research, P.O. Box 47, 6700 AA Wageningen, The Netherlands

b Laboratory of Microbiology, Wageningen University \& Research, P.O. Box 47, 6700 AA Wageningen, The Netherlands

c Department of Soil Quality, Wageningen University, P.O. Box 47, 6700 AA Wageningen, The Netherlands 
Culture Enrichment Processes. The sludge used for aerobic enrichment culture preparation was sampled from the inlet of the wastewater treatment plant in Bennekom (the Netherlands). The working volume was $100 \mathrm{ml}$, with $10 \%$ sludge and $4 \mathrm{mg} / \mathrm{L} \mathrm{2,4-D}$ and $90 \mathrm{ml}$ aerobic media (Table S2). The bottles were sealed and kept in dark at $20^{\circ} \mathrm{C}$, shaking at $120 \mathrm{rpm}$. 2,4-D concentration was measure frequently since $2,4-\mathrm{D}$ biodegradation was fast in the presence of $\mathrm{O}_{2}$. When $75 \%$ of $2,4-\mathrm{D}$ was degraded, 2,4-D was re-spiked. $10 \mathrm{ml}$ of the liquid phase which contained 2,4-D degraders was transferred to a new batch bottle one day after the re-spike. The recipe of the new batch bottle was similar to the initial ones: 100 $\mathrm{ml}$ working volume, with $10 \%$ biomass and $4 \mathrm{mg} / \mathrm{L} \mathrm{2,4-D.} \mathrm{When} 75 \%$ of 2,4-D was degraded, we respiked and made another transfer. Four transfers were performed in total. Each transfer took 3 to 4 days. During the enrichment process, oxygen concentration in gas phase was also measured. The batch bottle was flushed with air when the percentage of oxygen was lower than $10 \%$. Nitrification was inhibited by adding allylthiourea ( $5 \mathrm{mg} / \mathrm{L})$. 
Table S1. Physico-chemical properties of the pesticides used in this study, 2,4-dichlorophenoxyacetic acid (2,4-D), 2,6-dichlorobenzamide (BAM), mecoprop-p (MCPP) and bentazone.

\begin{tabular}{|c|c|c|c|c|c|c|c|c|c|}
\hline Pesticides & CAS number & $\begin{array}{l}\text { Molecular } \\
\text { structure }\end{array}$ & $\begin{array}{c}\text { Molecular } \\
\text { weight }\end{array}$ & $\begin{array}{l}\text { Solubility in water } \\
\left(\mathrm{pH}=7,25^{\circ} \mathrm{C}, \mathrm{g} / \mathrm{L}\right)\end{array}$ & $\begin{array}{c}\text { pKa }^{\text {a }} \text { (most acidic, } \\
25^{\circ} \mathrm{C} \text { ) }\end{array}$ & $\begin{array}{c}\text { LogKow }^{b} \\
(\mathrm{pH}=7, \\
\left.20^{\circ} \mathrm{C}\right)\end{array}$ & $\begin{array}{c}\log D_{o w}{ }^{c} \\
\left(p H=7,25^{\circ} \mathrm{C}\right)\end{array}$ & $\begin{array}{c}\text { DT50 }^{d} \\
\text { (aerobic, } \\
\text { days) }\end{array}$ & $\begin{array}{c}\text { Mobility }^{\mathrm{e}} \\
(\mathrm{pH}=7 \\
\left.25^{\circ} \mathrm{C}\right)\end{array}$ \\
\hline $\begin{array}{l}\text { 2,4-dichlorophenoxyacetic acid } \\
\qquad(2,4-D)\end{array}$ & $94-75-7$ & & 221 & 999 & $2.98 \pm 0.10$ & -0.82 & -1.14 & 4.4 & Very mobile \\
\hline 2,6-dichlorobenzamide (BAM) & $2008-58-4$ & & 190 & 0.61 & $14.73 \pm 0.50$ & 0.38 & 0.8 & 137.7 & Mobile \\
\hline Mecoprop (MCPP) & $93-65-2$ & & 214.6 & 1000 & $3.19 \pm 0.10$ & -0.19 & -0.92 & 8.2 & Very mobile \\
\hline Bentazone & $25057-89-0$ & & 240.3 & 8.4 & $3.28 \pm 0.70$ & -0.46 & 0.81 & 20 & Very mobile \\
\hline
\end{tabular}

a Dissociation Constants

b Octanol/Water Partition Coefficient

c $\mathrm{pH}$-dependent hydrophobicity value

d half life time (days)

e Soil Organic Carbon-Water Partitioning Coefficient Koc:

Koc<15: Very mobile;

$15<$ Koc $<75$ : Mobile:

$75<$ Koc<500: Moderately mobile;

$50<$ Koc $<4000$ : Slightly mobile; 
Koc $>4000=$ Non-mobile

Data sources: Solubility, pKa, Log Dow and Koc are from SciFinder (https://scifinder.cas.org/); LogKow, and DT50 are from Pesticide Properties DataBase (PPDB, http://sitem.herts.ac.uk/aeru/ppdb/en/atoz.htm); Mobility based on Koc values is from Agricultural Substances Database Background and Support Information http://sitem.herts.ac.uk/aeru/iupac/docs/Background and Support.pdf 
Table S2. Media composition for different redox conditions. Media was flushed with $\mathrm{N}_{2}$ and did not contain $\mathrm{O}_{2}$ (Lindeboom et al., 2011).

\begin{tabular}{|c|c|c|c|c|c|c|}
\hline \multirow{2}{*}{\multicolumn{2}{|c|}{$\begin{array}{l}\text { Compounds and concentration in media } \\
\qquad \mathrm{mg} / \mathrm{L}\end{array}$}} & \multirow[b]{2}{*}{$\begin{array}{l}\text { Batch } \\
\text { experiments }\end{array}$} & \multicolumn{4}{|c|}{ Column experiments } \\
\hline & & & $\begin{array}{l}\text { Nitrate- } \\
\text { reducing }\end{array}$ & $\begin{array}{l}\text { No electron } \\
\text { acceptor } \\
\text { amendment }\end{array}$ & $\begin{array}{l}\text { Sulfate- } \\
\text { reducing }\end{array}$ & $\begin{array}{l}\text { Methanogeni } \\
\text { c }\end{array}$ \\
\hline \multicolumn{7}{|c|}{$\mathrm{pH}$ buffer } \\
\hline $\mathrm{NaH}_{2} \mathrm{PO}_{4}$ & 234 & $\sqrt{ }$ & $\sqrt{ }$ & $\sqrt{ }$ & $\sqrt{ }$ & $\sqrt{ }$ \\
\hline $\mathrm{Na}_{2} \mathrm{HPO}_{4}$ & 433 & $\sqrt{ }$ & $\sqrt{ }$ & $\sqrt{ }$ & $\sqrt{ }$ & $\sqrt{ }$ \\
\hline \multicolumn{7}{|c|}{ Trace element solution } \\
\hline EDTA (tripex 2) & 0.6 & $\sqrt{ }$ & $\sqrt{ }$ & $\sqrt{ }$ & $\sqrt{ }$ & $\sqrt{ }$ \\
\hline $\mathrm{FeCl}_{2} \cdot 4 \mathrm{H}_{2} \mathrm{O}$ & 1.2 & $\sqrt{ }$ & $\sqrt{ }$ & $\sqrt{ }$ & $\sqrt{ }$ & $\sqrt{ }$ \\
\hline $\mathrm{MnCl}_{2} \cdot 4 \mathrm{H}_{2} \mathrm{O}$ & 0.3 & $\sqrt{ }$ & $\sqrt{ }$ & $\sqrt{ }$ & $\sqrt{ }$ & $\sqrt{ }$ \\
\hline $\mathrm{CoCl}_{2} \cdot 6 \mathrm{H}_{2} \mathrm{O}$ & 1.2 & $\sqrt{ }$ & $\sqrt{ }$ & $\sqrt{ }$ & $\sqrt{ }$ & $\sqrt{ }$ \\
\hline $\mathrm{CuCl}_{2} \cdot 2 \mathrm{H}_{2} \mathrm{O}$ & 0.018 & $\sqrt{ }$ & $\sqrt{ }$ & $\sqrt{ }$ & $\sqrt{ }$ & $\sqrt{ }$ \\
\hline $\mathrm{ZnCl}_{2}$ & 0.03 & $\sqrt{ }$ & $\sqrt{ }$ & $\sqrt{ }$ & $\sqrt{ }$ & $\sqrt{ }$ \\
\hline $\mathrm{HBO}_{3}$ & 0.03 & $\sqrt{ }$ & $\sqrt{ }$ & $\sqrt{ }$ & $\sqrt{ }$ & $\sqrt{ }$ \\
\hline$\left(\mathrm{NH}_{4}\right)_{6} \mathrm{Mo}_{7} \mathrm{O}_{24} \cdot 4 \mathrm{H}_{2} \mathrm{O}$ & 0.05 & $\sqrt{ }$ & $\sqrt{ }$ & $\sqrt{ }$ & $\sqrt{ }$ & $\sqrt{ }$ \\
\hline $\mathrm{Na}_{2} \mathrm{SeO}_{3} \cdot 5 \mathrm{H}_{2} \mathrm{O}$ & 0.06 & $\sqrt{ }$ & $\sqrt{ }$ & $\sqrt{ }$ & $\sqrt{ }$ & $\sqrt{ }$ \\
\hline $\mathrm{NiCl}_{2} \cdot 6 \mathrm{H}_{2} \mathrm{O}$ & 0.03 & $\sqrt{ }$ & $\sqrt{ }$ & $\sqrt{ }$ & $\sqrt{ }$ & $\sqrt{ }$ \\
\hline $\mathrm{HCl} 36 \%$ & 0.0006 & $\sqrt{ }$ & $\sqrt{ }$ & $\sqrt{ }$ & $\sqrt{ }$ & $\sqrt{ }$ \\
\hline Resazurin & 0.3 & $\sqrt{ }$ & $\sqrt{ }$ & $\sqrt{ }$ & $\sqrt{ }$ & $\sqrt{ }$ \\
\hline \multicolumn{7}{|c|}{ Macro nutrients } \\
\hline $\mathrm{NH}_{4} \mathrm{Cl}$ & 1020 & $\sqrt{ }$ & $\sqrt{ }$ & $\sqrt{ }$ & $\sqrt{ }$ & $\sqrt{ }$ \\
\hline $\mathrm{CaCl}_{2} \cdot 2 \mathrm{H}_{2} \mathrm{O}$ & 48 & $\sqrt{ }$ & $\sqrt{ }$ & $\sqrt{ }$ & $\sqrt{ }$ & $\sqrt{ }$ \\
\hline $\mathrm{MgSO}_{4} \cdot 7 \mathrm{H}_{2} \mathrm{O}$ & 54 & $\sqrt{ }$ & $\sqrt{ }$ & $\sqrt{ }$ & $\sqrt{ }$ & $\sqrt{ }$ \\
\hline \multicolumn{7}{|c|}{ Redox specific compounds } \\
\hline $\mathrm{NaNO}_{3}$ & 850 & & $\sqrt{ }$ & & & \\
\hline $\mathrm{Na}_{2} \mathrm{SO}_{4}$ & 1190 & & & & $\sqrt{ }$ & \\
\hline $\mathrm{Na}_{2} \mathrm{~S} \cdot 9 \mathrm{H}_{2} \mathrm{O}$ & 120 & & & & $\sqrt{ }$ & $\sqrt{ }$ \\
\hline
\end{tabular}


Table S3. Information about aquifer material samples for the four columns. All samples were taken at Eijbergen in the East of the Netherlands. Core samples were taken to gain undisturbed soil samples and retain the anaerobic conditions within the soil to keep the microorganisms in an environment comparable to the field situation. mbgl: meters below ground level.

\begin{tabular}{l|l|l|l}
\hline $\begin{array}{l}\text { Sampling depth } \\
(\mathrm{mbgl})\end{array}$ & Soil type & $\begin{array}{l}\text { Average organic } \\
\text { matter \% }\end{array}$ & $\begin{array}{l}\text { Average } \\
\text { porosity \% }\end{array}$ \\
\hline $1-10$ & $\begin{array}{l}\text { Mainly sand, some } \\
\text { clay and peat }\end{array}$ & $0.95 \pm 0.60$ & $35 \pm 4.08$ \\
& & & \\
\hline
\end{tabular}

Table S4. qPCR amplification of the functional genes

\begin{tabular}{|c|c|c|c|c|}
\hline $\begin{array}{l}\text { Target } \\
\text { gene }\end{array}$ & $\begin{array}{l}\text { Primer names (if applicable) and oligonucleotide } \\
\text { sequence }\end{array}$ & Thermal profile & Cycles & Ref. \\
\hline$t f d A$ & $\begin{array}{l}\left(5^{\prime}-\text { GAGCACTACGCRCTGAAYTCCCG-3') }\right. \\
\left(5^{\prime}-\text { GTCGCGTGCTCGAGAAG-3') }\right.\end{array}$ & $\begin{array}{l}95^{\circ} \mathrm{C} 10 \mathrm{~min} \\
95^{\circ} \mathrm{C} 30 \mathrm{~s}, 55^{\circ} \mathrm{C} 30 \mathrm{~s}, \text { gradient } \\
56^{\circ} \mathrm{C} \text { to } 67^{\circ} \mathrm{C} 30 \mathrm{~s}, 72^{\circ} \mathrm{C} 30 \mathrm{~s} \\
72^{\circ} \mathrm{C} 7 \text { min }\end{array}$ & $\begin{array}{c}1 \\
46 \\
1\end{array}$ & $\begin{array}{l}\text { (Bælum et al., } \\
\text { 2012) }\end{array}$ \\
\hline nirk & $\begin{array}{l}\text { nirK876 (5'-ATYGGCGGVCAYGGCGA-3') } \\
\text { nirK1040 (5'-GCCTCGATCAGRTTGTGGTT-3') }\end{array}$ & $\begin{array}{l}95^{\circ} \mathrm{C} 10 \mathrm{~min} \\
95^{\circ} \mathrm{C} 15 \mathrm{~s}, 60^{\circ} \mathrm{C} 30 \mathrm{~s}, 72^{\circ} \mathrm{C} 30 \\
\mathrm{~s}\end{array}$ & $\begin{array}{c}1 \\
46\end{array}$ & $\begin{array}{l}\text { (Henry et al., } \\
\text { 2004) }\end{array}$ \\
\hline nirs & $\begin{array}{l}\text { nirS cd3AF (5'-AACGYSAAGGARACSGG-3') } \\
\text { nirS R3cd (5'-GASTTCGGRTGSGTCTTSAYGAA-3') }\end{array}$ & $\begin{array}{l}95^{\circ} \mathrm{C} 5 \mathrm{~min} \\
95^{\circ} \mathrm{C} 15 \mathrm{~s}, 56^{\circ} \mathrm{C} 30 \mathrm{~s}, 72^{\circ} \mathrm{C} 30 \\
\mathrm{~s}\end{array}$ & $\begin{array}{c}1 \\
46\end{array}$ & $\begin{array}{l}\text { (Michotey et al., } \\
\text { 2000; Throbäck } \\
\text { et al., 2004) }\end{array}$ \\
\hline nosZ & $\begin{array}{l}\operatorname{nos} Z 2 \mathrm{~F}\left(5^{\prime}-\mathrm{CGCRACGGCAASAAGGTSMSSGT-3')}\right. \\
\operatorname{nos} Z 2 \mathrm{R}\left(5^{\prime}-\mathrm{CAKRTGCAKSGCRTGGCAGAA-3')}\right.\end{array}$ & $\begin{array}{l}95^{\circ} \mathrm{C} 10 \mathrm{~min} \\
95^{\circ} \mathrm{C} 30 \mathrm{~s}, 60^{\circ} \mathrm{C} 30 \mathrm{~s}, 72^{\circ} \mathrm{C} 30 \\
\mathrm{~s}\end{array}$ & $\begin{array}{c}1 \\
46\end{array}$ & $\begin{array}{l}\text { (Henry et al., } \\
\text { 2006) }\end{array}$ \\
\hline$d s r B$ & $\begin{array}{l}\text { DSRp2060F-GC(5'-CAACATCGTYCAYACCCAGGG- } \\
\text { 3') } \\
\text { DSR4R (5'-GTGTAGCAGTTACCGCA-3') }\end{array}$ & $\begin{array}{l}95^{\circ} \mathrm{C} 3 \mathrm{~min} \\
95^{\circ} \mathrm{C} 30 \mathrm{~s}, 48^{\circ} \mathrm{C} 45 \mathrm{~s}, 72^{\circ} \mathrm{C} 30 \\
\mathrm{~s} \\
\text { followed by } \\
95^{\circ} \mathrm{C} 30 \mathrm{~s}, 58^{\circ} \mathrm{C} 45 \mathrm{~s}, 72^{\circ} \mathrm{C} 30 \\
\mathrm{~s}\end{array}$ & $\begin{array}{l}1 \\
6 \\
40\end{array}$ & $\begin{array}{l}\text { (Dar et al., } \\
\text { 2007) }\end{array}$ \\
\hline $\begin{array}{l}\text { Bacteria } \\
16 S \text { rRNA }\end{array}$ & $\begin{array}{l}\text { Eub341F(5-CCTACGGGAGGCAGCAG-3') } \\
\text { Eub534R (5'-ATTACCGCGGCTGCTGGC-3') }\end{array}$ & $\begin{array}{l}95^{\circ} \mathrm{C} 10 \mathrm{~min} \\
95^{\circ} \mathrm{C} 20 \mathrm{~s}, 60^{\circ} \mathrm{C} 30 \mathrm{~s}, 72^{\circ} \mathrm{C} 30 \\
\mathrm{~s}\end{array}$ & $\begin{array}{c}1 \\
40\end{array}$ & $\begin{array}{l}\text { (Muyzer et al., } \\
\text { 1993) }\end{array}$ \\
\hline $\begin{array}{c}\text { Archaea } \\
16 S\end{array}$ & $\begin{array}{l}\text { Arc787F (5'-ATTAG ATACC CSBGT AGTCC-3') } \\
\text { Arc1059R (5'-GCCAT GCACC WCCTC T-3') }\end{array}$ & $\begin{array}{l}95^{\circ} \mathrm{C} 10 \mathrm{~min} \\
95^{\circ} \mathrm{C} 10 \mathrm{~s}, 60^{\circ} \mathrm{C} 30 \mathrm{~s}\end{array}$ & $\begin{array}{c}1 \\
40\end{array}$ & $\begin{array}{c}\text { (Muyzer et al., } \\
1993)\end{array}$ \\
\hline
\end{tabular}

Table S5. Cumulative $\mathrm{O}_{2}$ consumption and $\mathrm{CO}_{2}$ production during 14 days in batch pre-experiments.

\begin{tabular}{l|l|l}
\hline & $\begin{array}{l}\mathrm{O}_{2} \text { consumption } \\
(\mathrm{mmol} / \mathrm{L})\end{array}$ & $\begin{array}{l}\mathrm{CO}_{2} \text { production } \\
(\mathrm{mmol} / \mathrm{L})\end{array}$ \\
\hline Without DOM addition & $1.179 \pm 0.102$ & $0.617 \pm 0.009$ \\
\hline Addition of DOM & $1.275 \pm 0.028$ & $0.643 \pm 0.005$ \\
\hline Addition of DOM & $1.240 \pm 0.034$ & $0.646 \pm 0.012$ \\
\hline
\end{tabular}



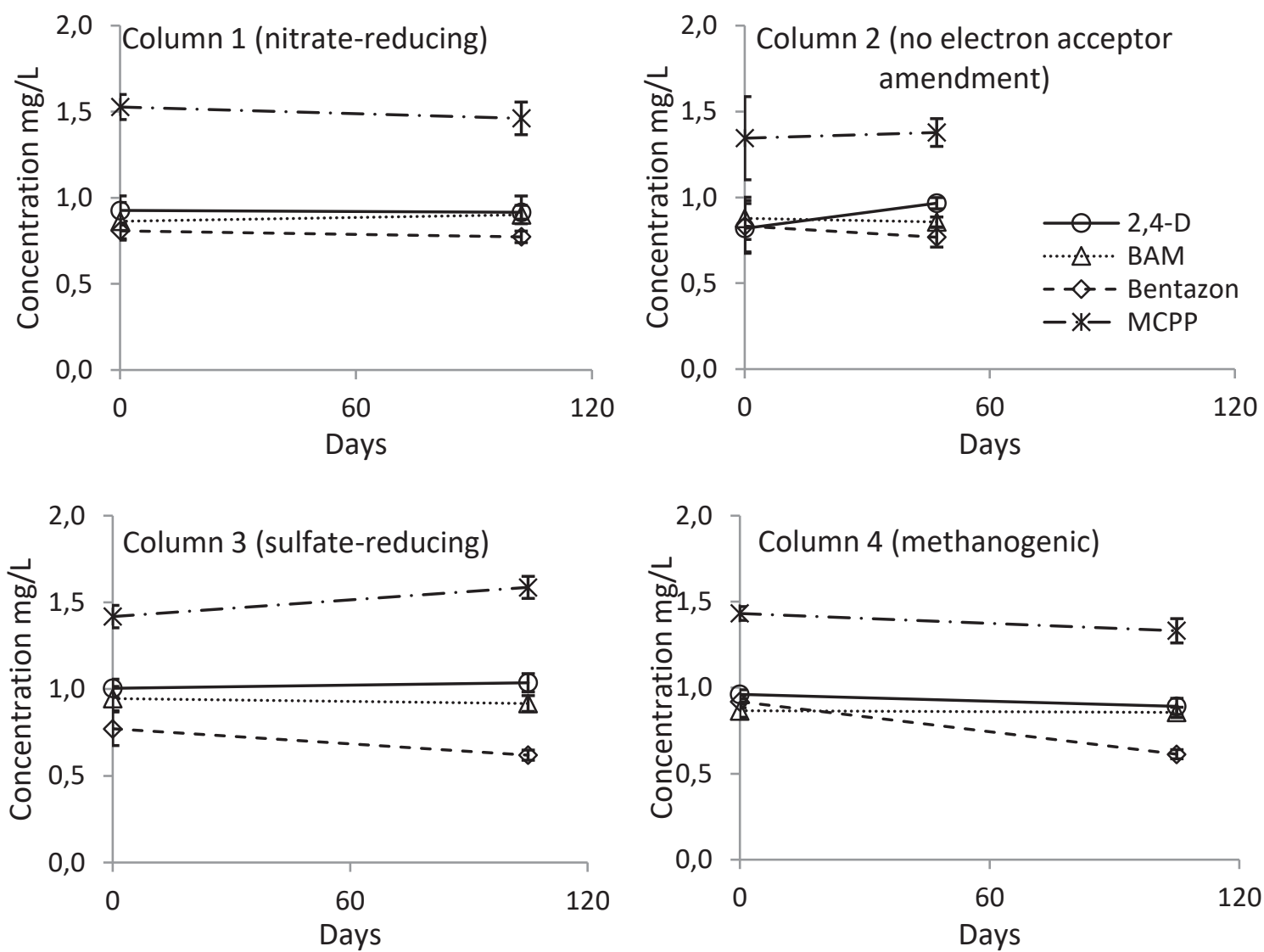

Figure S1. Abiotic batch test of pesticide biodegradation under different redox conditions in incubation of aquifer materials applied to column experiments. $2 \mathrm{mM} \mathrm{NaN}_{3}$ and $1 \mathrm{mM}$ of $\mathrm{HgCl}_{2}$ were applied to inhibit microbial activity. 


\section{Column 1 (nitrate-reducing)}
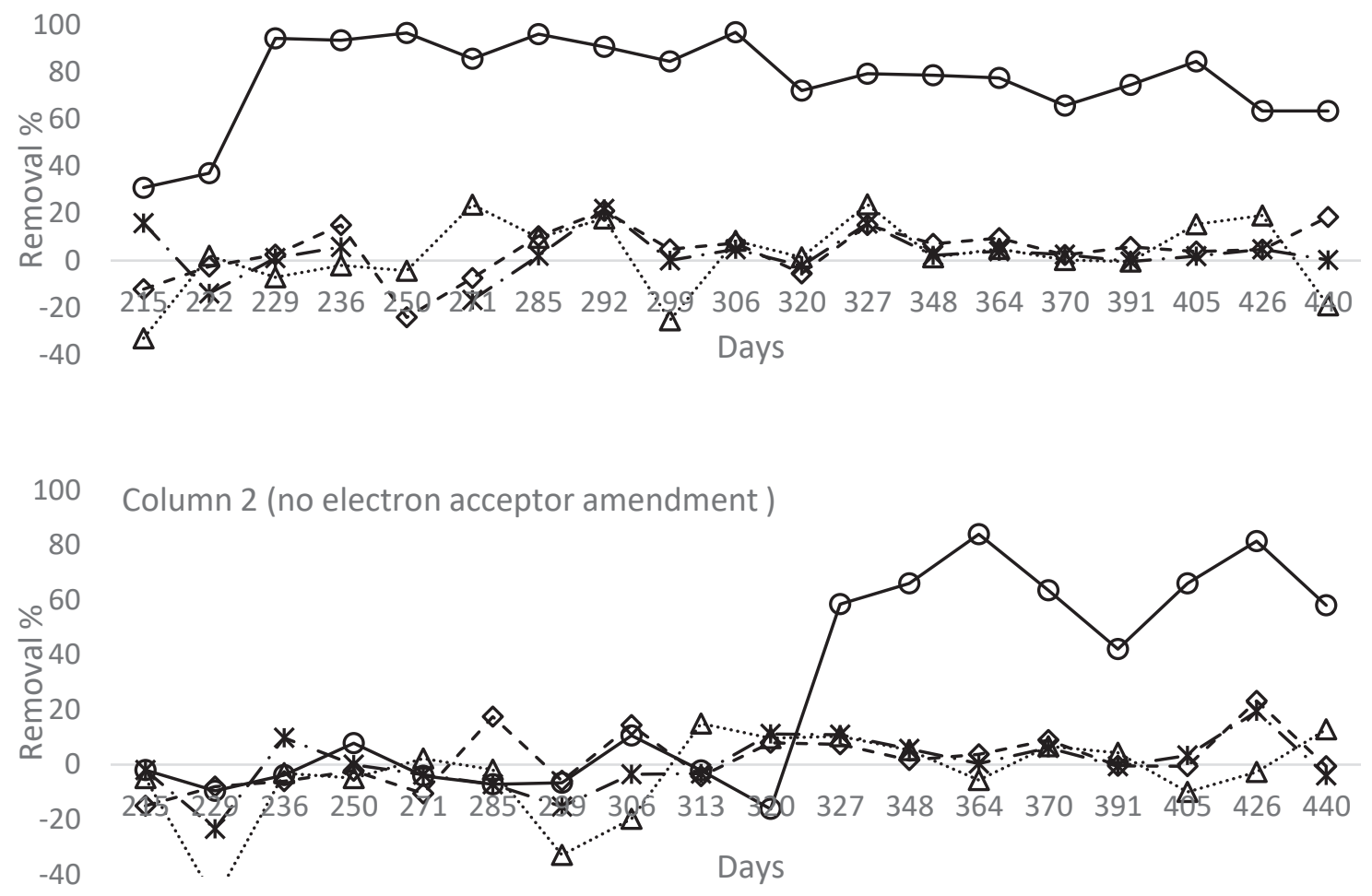

Column 3 (sulfate-reducing)
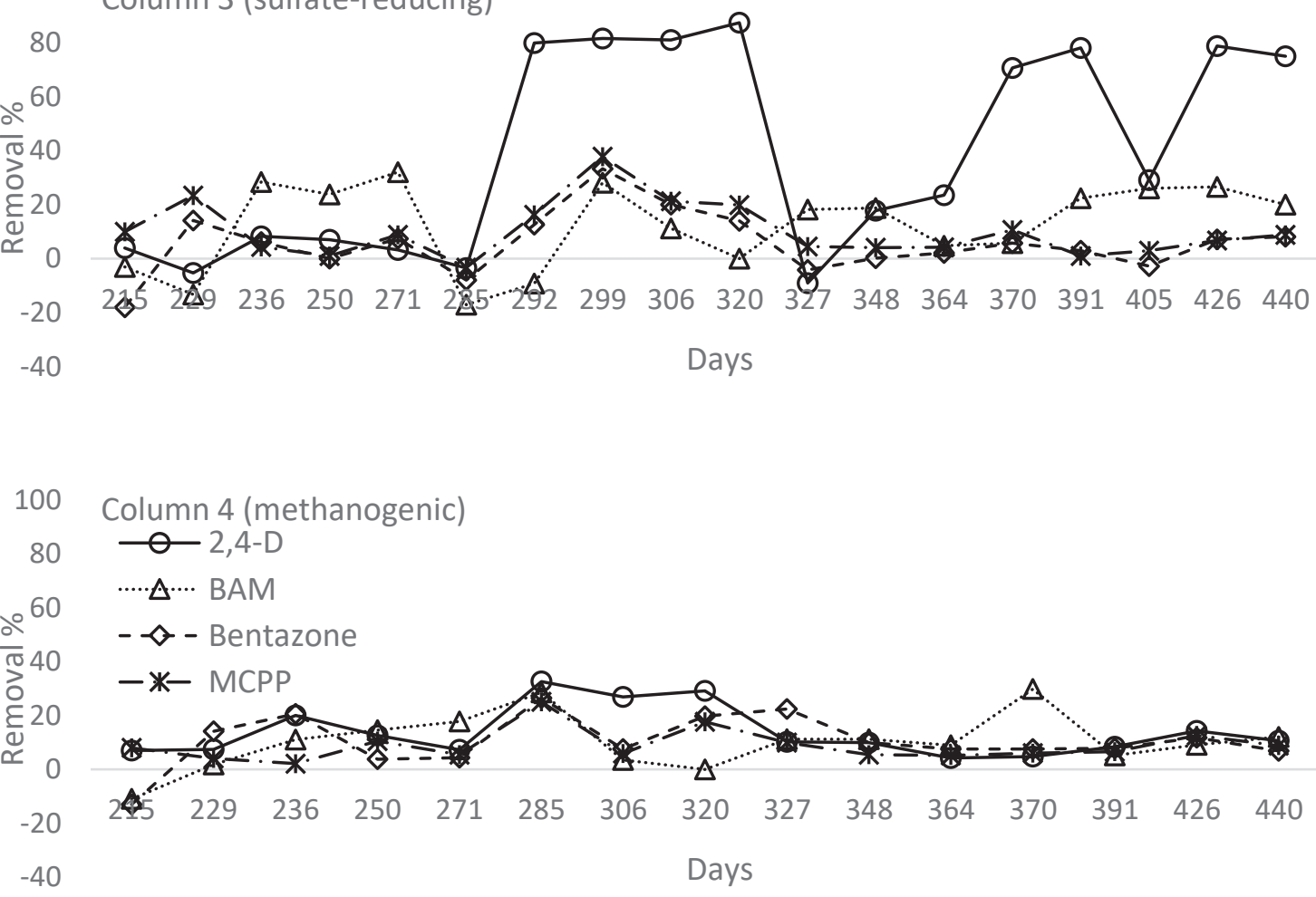

Figure S2. Point data of pesticide biodegradation from day 215 to day 440 . DOMcompost was added at day 229. 

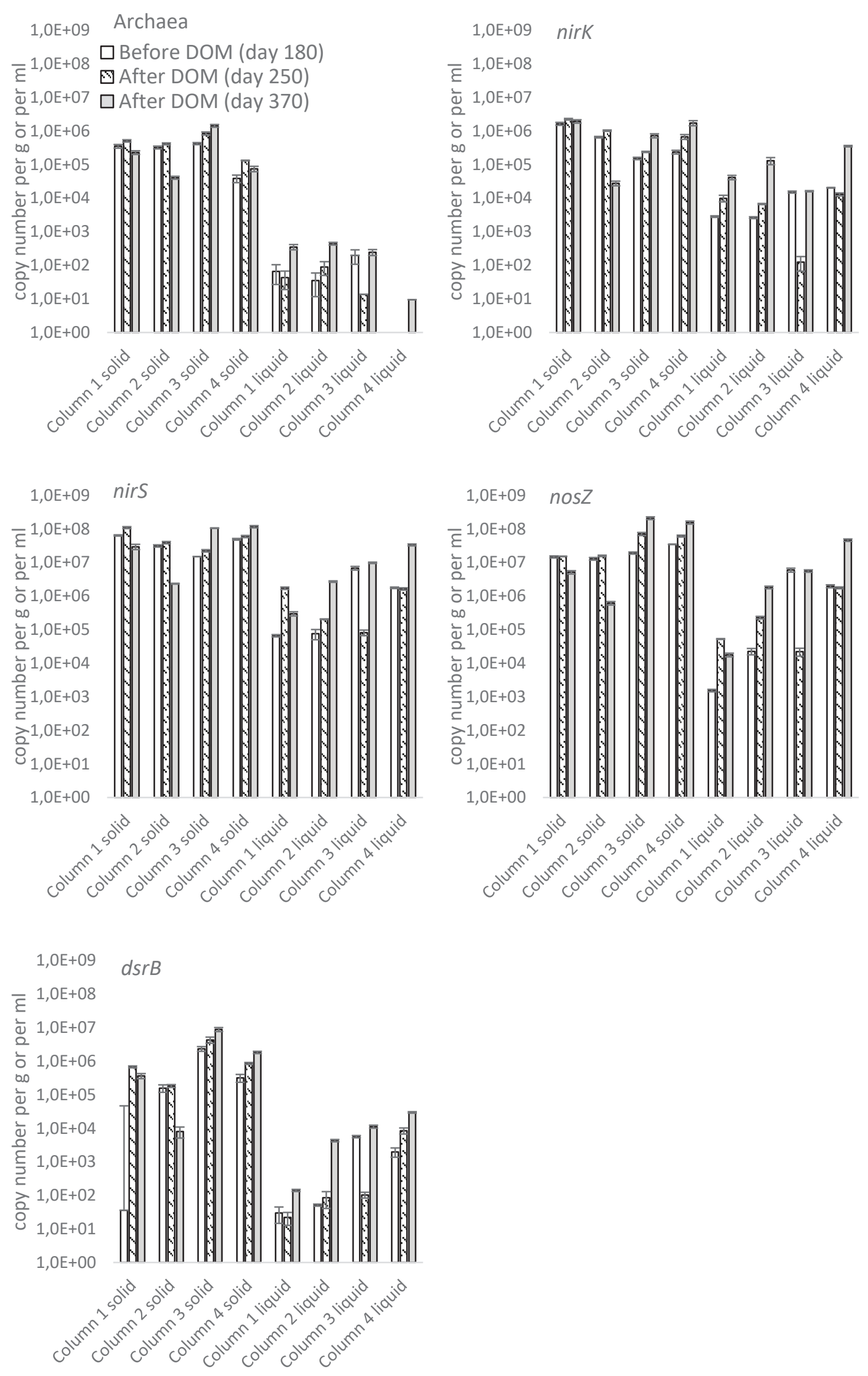
Figure S3. 16S rRNA gene copy number of archaea, and key functional genes of denitrifying bacteria (nirk, nirS, nosZ), and sulfate reducers (dsrB) before DOM addition (at day 180) and after DOM addition (at day 250 and day 370) under all redox conditions from solid and liquid phase samples. Column 1 was nitrate-reducing; Column 2 received no electron acceptor amendment; Column 3 was sulfate-reducing;

Column 4 was methanogenic. All qPCR results are the average of triplicate assays with standard deviation.

\section{Reference}

Bælum J, Prestat E, David MM, Strobel BW, Jacobsen CS. Modeling of phenoxy acid herbicide mineralization and growth of microbial degraders in 15 soils monitored by quantitative real-time PCR of the functional tfdA gene. Applied \& Environmental Microbiology 2012; 78: 5305.

Dar SA, Li Y, Dongen UV, Kuenen JG, Muyzer G. Analysis of diversity and activity of sulfate-reducing bacterial communities in sulfidogenic bioreactors using 16S rRNA and dsrB genes as molecular markers. Applied \& Environmental Microbiology 2007; 73: 594.

Henry S, Baudoin E, López-Gutiérrez JC, Martin-Laurent F, Brauman A, Philippot L. Quantification of denitrifying bacteria in soils by nirk gene targeted real-time PCR. Journal of Microbiological Methods 2004; 59: 327-335.

Henry S, Bru D, Stres B, Hallet S, Philippot L. Quantitative detection of the nosZ gene, encoding nitrous oxide reductase, and comparison of the abundances of $16 \mathrm{~S}$ rRNA, narG, nirK, and nosZ genes in soils. Applied \& Environmental Microbiology 2006; 72: 5181.

Lindeboom R, Fermoso F, Weijma J, Zagt K, Van Lier J. Autogenerative high pressure digestion: anaerobic digestion and biogas upgrading in a single step reactor system. Water science and technology 2011; 64: 647-653.

Michotey V, Méjean V, Bonin P. Comparison of Methods for Quantification of Cytochrome cd 1-Denitrifying Bacteria in Environmental Marine Samples. Applied \& Environmental Microbiology 2000; 66: 1564-71.

Muyzer G, de Waal EC, Uitterlinden AG. Profiling of complex microbial populations by denaturing gradient gel electrophoresis analysis of polymerase chain reaction-amplified genes coding for 16S rRNA. Applied \& Environmental Microbiology 1993; 59: 695.

Throbäck IN, Enwall K, Jarvis A, Sa, Hallin S. Reassessing PCR primers targeting nirS, nirK and nosZ genes for community surveys of denitrifying bacteria with DGGE, 2004. 